\title{
Partisan-electoral cycles in public employment: evidence from developed democracies
}

\begin{abstract}
According to both early empirical findings and theoretical expectations of partisan preferences, leftwing parties in government ought to prefer higher levels of public employment for both ideological and opportunistic reasons. In contrast, using country-fixed effects in a panel of 22 OECD countries, this article finds no evidence of left-wing governments systematically increasing public employment. However, there is evidence that left-wing governments increase public employment in election years, which gives rise to an opportunistic, partisan-electoral cycle in public employment. In line with the logic of core-voter targeting and political budget cycles, incumbent left-wing parties seem to increase the number of their potential core voters when they are needed most.
\end{abstract}

Keywords: Partisanship; public employment; political budget cycles, elections 


\section{Introduction}

This article investigates whether and under which circumstances left-wing governments increase the level of public employment. At least since Hibbs' (1977) work on the policy effects of political parties, questions regarding partisan differences and cycles in economic policymaking and government spending have been at the forefront of empirical and theoretical research in political science and political economy. There has been extensive research on whether left-wing governments have at least short-term effects on growth, inflation, unemployment, redistribution, size of the public sector, and labour market policies (Frey and Schneider, 1978; Blais et al., 1993; Alesina et al., 1997; Cusack, 1997; Heckelman, 2006; Iversen and Soskice, 2006; Chang et al., 2013; Mechtel and Potrafke, 2013) - see Potrafke (2017) for a recent review of the partisan politics literature. The conclusions from these empirical studies are generally mixed, possibly because the detection of partisan effects on macroeconomic and other policy outcomes are heavily conditioned on other economic and political factors (Franzese, 2002: 406-412; Häusermann et al., 2013: 229-232).

This article investigates the partisan effects on one important aspect of public policy priorities, which has been empirically studied to a lesser degree: the level of and changes in public sector employment. Given that public employment as a share of total employment exhibits great variation, both between and within countries, even among developed democracies, and is a clear indicator of public vs. private production. ${ }^{1}$ And as a larger public sector is often seen as a left-wing policy preference, it should be a prime indicator of a partisan effect on public policy. Consequently, we would expect a positive relationship between left-wing government control and a higher level of government employment, a finding confirmed by early empirical work (Murrel, 1985; Cusack et al., 1989). These earlier comparative studies of partisan effects on public employment mainly rely on cross-sectional data, however, and possibly capture country-specific idiosyncrasies rather than any true effect of partisanship on public employment levels. Furthermore, these studies usually do not

1 Healthcare and education provide obvious examples, where considerable variation in the employment status of health care personnel and teaching personnel exists between countries and in countries over time, which is partly a function of differences in public policies (OECD, 2014: 406; OECD, 2015a: chapter 9). 
distinguish between the underlying reasons for why left-wing governments should increase public employment, including whether their motivations are ideological or opportunistic.

This article addresses these topics by theorising about both ideological and opportunistic reasons for why left-wing governments would want to increase public employment, and tests the respective empirical implications using data from 22 OECD countries between 1995 and 2010. Applying fixed effects regression, no independent, statistically significant effect of left-wing control of government can be found on the level of public employment. However, leftist governments seem to increase public employment in election years, giving rise to a combined partisan-electoral cycle in public employment. The results suggest that left-wing governments try to increase and mobilise potential core supporters when they need them most, and the effect of left-wing governments on public employment appears to be caused by opportunistic (rather than purely ideological) concerns. This effect only holds for elections held in years when they are scheduled, which further indicates that left-wing governments time public personnel decisions to elections when able to do so. Public employment thus seems to be an area where left-wing parties attempt to use public policies to make politics (Anzia and Moe, 2016: 763) in their favour in the short run.

The findings in this article contribute to the wider literature on partisan policymaking and political budget cycles by specifically addressing the public employment issue. The results indicate that public employment is affected by a combination of partisan and electoral-opportunistic forces, in line with the focus in the more recent literature on the conditionality of political cycles (Alt and Rose, 2007; Dubois, 2016: 244-248). These findings are also of interest for the wider literature on the political economy of public employment (Alesina et al., 2000; Gimpelson and Treisman, 2002; Cahan, 2019), as the combination of elections and partisanship has a potential, non-trivial effect on public employment levels.

The next section reviews some of the earlier literature on government ideology and public employment, which is then followed by a section that discusses the theoretical explanations for potential partisan effects on public employment, and lays out the hypotheses. This is followed by a 
description of the dataset, data sources, and estimation used to test the potential partisan effects on public employment. I then present the baseline results from the tests of the impact of left-wing governments on public employment and explore the interaction between left-wing government control and elections, before testing the robustness of these main results. The final section concludes and discusses avenues for further research.

\section{Previous literature: Public employment and government ideology}

In accordance with the partisan view of government policymaking, early work by Murrel (1985) and Cusack et al. (1989) finds the size of public employment to be positively associated with the electoral representation of left-wing parties. In a study of employment in French hospitals, Clark and Milcent (2011) find an indication that left-wing local governments increase public hospital staff more than right-wing local governments when local unemployment is higher, which is in accordance with the influential view that public employment can be used as a politically convenient redistribution tool (Alesina et al., 2000). However, as partisan effects on fiscal policy seem to have weakened over time (Cusack, 1999), the question becomes whether this apparent effect of left partisanship on public employment still holds in recent decades. Another concern is that Murrel (1985) as well as Cusack et al., (1989) mainly use cross-sectional data to address the question of the partisan effect of public employment, meaning that they might instead capture national nonobserved institutional differences and idiosyncrasies, which affect both public employment and left partisanship.

With regards to the role played by political incentives for public employment, a large and growing literature deals with electoral political budget cycles - opportunistic election-year fiscal expansions (Rogoff, 1990), in public employment. Electoral cycles in public employment have been detected in Finnish and Swedish municipalities (Dahlberg and Mörk, 2011), German states (Tepe and Vanhuyesse, 2009, 2013), and US cities (Bee and Moulton, 2015) as well as US states and counties (Cahan, 2019). ${ }^{2}$ However, whether the ideological inclinations of policymakers play any role for

\footnotetext{
${ }^{2}$ In a recent paper, Aaskoven (2016) also finds contingent electoral cycles in public employment in OECD countries.
} 
these electoral cycles in public employment has received less attention, with the exception of Cahan (2019), who finds electoral cycles in public employment in US states to be larger under Democratic incumbents.

This article investigates the effect of left-wing parties for the level of public employment in a comparative perspective over time, where the use of country-fixed effects enables me to hold country-specific confounders constant. Furthermore, the article theorizes and investigates whether an apparent effect of left-wing governments on a higher level of public employment is due to ideological or opportunistic motivations by investigating the combined effect of government ideology and electoral incentives in a comparative perspective. Thus, this article brings new aspects to the literature on the role left-wing parties and electoral incentives play for the level and growth of public employment in developed democracies.

\section{Theory and hypotheses}

This section describes the theoretical background for why we would expect left-wing governments to have a positive effect on public employment levels. There are at least two reasons for these expectations: one purely ideological, the other opportunistic. Both of them give rise to different testable hypotheses.

The ideological reason is based on the common assumption that left-wing governments are more pro public sector and want to increase the public relative to the private sector. The assumption that political parties hold different ideological preferences underlines most theoretical models of partisan cycles (Alesina et al., 1997: chapter 3) as well as many empirical studies on the effect of left-wing parties on public policy. Empirical research on developed democracies generally points to differences in the ideological stance of the government as one of the predictors of the size of the public sector (Blais et al., 1993; Cusack, 1997) and whether the government uses tax increases or spending cuts in times of fiscal consolidation (Tavares, 2004). Consequently, we would expect leftwing governments to prefer higher levels of public vs. private production than centrist and rightwing governments. Since a higher level of public employment is clearly a sign of higher public vs. 
private production, a left-wing government would be expected to increase public employment as a share of total employment.

Furthermore, expanding public employment might also increase employment opportunities for women (Iversen and Rosenbluth, 2010: 117) and strengthen organised labour, as union density tends to be higher in the public sector in most OECD countries (Visser, 2006: 46); these are issues we would expect to be prioritised by left-wing parties, at least in developed democracies. According to these arguments, left-wing parties ought to prefer higher levels of public employment relative to other types of political parties for ideological reasons. Consequently, they ought to pursue policies that raise and/or maintain public employment levels when in office, such as hiring additional employees in the central government sector, halting or rolling back the privatisation of publicly provided services, and abolishing or relaxing centrally imposed hiring restrictions for local and regional governments.

Obviously, as the central insights from the rational partisan models of economic policymaking make clear (Alesina et al., 1997: chapter 3), if the final policy outcomes also partly depend on the expectations and behaviour of the voters/citizens, partisan cycles might be short-lived and even non-existent in some cases. Unlike macroeconomic aggregates such as unemployment and inflation, however, public employment policies, like fiscal policy in general, would be easier for an incumbent government to directly control and manipulate through the policies mentioned above. So even taking rational expectations into account, we would expect ideologically motivated left-wing parties to be able to raise the level of public employment.

Summing up, we would expect a relatively higher share of public employees under a left-wing government due to left-wing ideological preferences. This line of argument gives rise to our first hypothesis.

Hypothesis $1(\mathrm{H1})$ : The level of public employment is higher under a left-wing government. 
The other reason for an expected impact of left-wing government partisanship on public employment is an opportunistic mechanism, which assumes that incumbent politicians are concerned with maximising votes, arguably the most classic assumption in formal theories in political science and political economy. ${ }^{3}$ Given that public servants in most developed countries tend to be more inclined to vote for left-of-centre parties, ${ }^{4}$ left-wing parties should intuitively wish to increase public employment levels to secure a larger share of core supporters in the electorate. This argument is in line with the theory of core-voter targeting, modelled by - among others - Cox and McCubbins (1986). Often contrasted with the rival theory of swing-voter targeting (Dixit and Londregan, 1996), core-voter targeting has become one of the workhorse models in the empirical and theoretical study of distributive politics (Golden and Min, 2013: 78-82).

The basic argument and implications of these models are that office-seeking political parties target material resources to mobilise and maintain core supporters. ${ }^{5}$ Previous research in core-voter targeting has generally taken the size of the core voter groups as given. Within the area of public employment, however, government policy can actually change the potential size of a given corevoter group, which vote-seeking incumbent governments could plausibly be expected to utilise. Timed increases in public employment levels would then be a viable strategy for an incumbent leftwing government to increase voter support. This argument bears similarities to the classic adage that policies make politics, where the argument is that enacted policies change the structure of a country's political constituencies and thereby provide feedback to the political system (Anzia and Moe, 2016: 763). In the case of left-wing parties and public employment, however, this could be

\footnotetext{
${ }^{3}$ At least since Downs (1957: 11). See also Strom's (1990) classic discussion of models of votemaximising parties and other types of party behaviour models.

${ }^{4}$ Although economic-institutional factors may determine the size and nature of this public-private employment voting gap. See Blais et al. (1990), Knutsen (2005), Tepe (2012), and Arndt (2013). ${ }^{5}$ Previous studies on distributive politics have both confirmed (Larcinese et al., 2013; Kauder et al., 2016) and rejected (Dahlberg and Johansson, 2002) the occurrence of core-voter targeting, which suggests that institutional settings and other conditioning factors might matter for the occurrence of core-voter vs. swing-voter targeting (Larcinese et al., 2013: 875; Golden and Min, 2013: 78-82).
} 
done strategically by incumbent left-wing governments in order to maximise the number of core voters. $^{6}$

However, we would expect this opportunistic mechanism to dominate in years in which left-wing governments actually need electoral support (i.e. election years). This line of argument follows the logic from the massive literature on political budget cycles or electoral budget cycles, where an incumbent government increases public spending/decreases public revenue immediately before elections in order to appear competent and/or buy direct voter support (Rogoff, 1990; Franzese, 2002; Shi and Svensson, 2006; Klomp and de Haan, 2013; Golden and Min, 2013: 83-84). That an incumbent left-wing government would concentrate public employment increases in election years is even more plausible when it is assumed that governments operate under budget constraints, as in most models of redistributive politics (Lindbeck and Weibull, 1987), which is arguably a realistic assumption. With limited funds, a vote-seeking incumbent left-wing government would concentrate increases in public employment to the years when electoral support is most needed and voter attention is greatest: election years (Rogoff, 1990; Healy and Lenz, 2014). The implication of these arguments gives rise to the second hypothesis.

Hypothesis 2 (H2): Left-wing governments increase the level of public employment more in election years.

\section{Dataset}

The dataset used to test the partisan effects of public employment consists of a panel of 22 OECD countries in the years 1995-2010. The countries are Australia, Austria, Belgium, Canada, Denmark, Finland, France, Germany, Greece, Ireland, Italy, Japan, Luxembourg, Netherlands, New Zealand, Norway, Portugal, Spain, Sweden, Switzerland, United Kingdom, and the United States. I have chosen to focus on these OECD countries as they are generally developed democracies with established political parties which can, for the most part, be fairly easily characterised as either left-

\footnotetext{
${ }^{6}$ Whether political parties actively expand their electoral bases and try to swing voters' ideological convictions in their own direction is a matter of some controversy. For a positive finding on this phenomenon, see Matsubayashi (2013) and Anzia and Moe (2016). Rogowski’s (2013: 218-219) pre-publication discussion of Ansell (2014) and Kurrild-Klitgaard (2011) provides opposing views.
} 
wing or non-left parties (especially for government parties), ${ }^{7}$ and where it is generally established that publically employed voters tend to favour left-wing parties (Blais et al., 1990; Knutsen, 2005). ${ }^{8}$ The timeframe of the dataset is determined by availability of the public employment data, which is described in more detail in the next section.

\section{Variables and data sources}

The dependent variable of interest is public employment as a share of total labour force. ${ }^{9}$ This variable provides a measure of the degree to which the available labour force is publicly employed and, consequently, the relative priority for public vs. private employment. It is therefore a suitable variable for measuring partisan preferences for the level of public employment. The data for total labour force is from the OECD databases, while I obtain data for public employment from the International Labour Organization's (ILO) LABORSTA database, which is the best available data source for the number of public employees over time, and is utilised by the OECD in its publications on public employment (OECD, 2015b: 84-85). Public employment is available at the yearly level from 1995 until 2010. The database coverage thus ends in 2010, which is therefore the final year of the panel. While the ILO's ILOSTAT database has public employment data from 2006 to 2018 , as of 2019 this updated public employment data does not seem to be fully comparable with the original public employment data in the LABORSTA database. Consequently, I have chosen to stick with using only the LABORSTA database as the source of the public employment data.

There are gaps in the public employment data for some countries in the dataset, especially early and late in the period, giving the data an unbalanced structure. Where possible, I include employees of publicly owned enterprises as public employees, since some countries rely on such enterprises to

\footnotetext{
${ }^{7}$ Consequently, most work on partisan policymaking concerns OECD countries (Potrafke, 2017).

${ }^{8}$ The theoretical arguments about the effect of left-wing governments on public employment levels might thus also apply in other countries of the world, as long as the conditions of established parties with a left-wing ideology and a general preference for left-wing parties among public sector employees are met.

${ }^{9}$ Various panel unit root tests generally suggest that this variable is stationary within the panel.
} 
conduct tasks executed by the official state apparatus in other countries. However, for some countries, such as Austria, only general government employment is available. The later estimation method uses country-fixed effects, so this data variation between a few countries should not be a concern.

It should be noted that the measure of public employment level concerns the general government public employment, and thus also subnational public employment in municipalities and other subnational units (including states in federal systems), while the political variables concern government ideology and election occurrence at the national level. This could cause some concern, since the central government is usually only directly responsible for public employment at the central government level. See Potrafke (2018) for discussions about these issues in the empirical study of the political economy of public employment. However, the LABORSTA database only records general government public employment, and alternative sources of central government public employment data are not readily available for OECD countries over the studied time period. Furthermore, in most OECD countries, the central government should be able to both indirectly and sometimes even directly affect the level of public employment at the municipal, regional, and even state level, through (targeted) intergovernmental grants, stricter or looser enforcement of subnational fiscal rules and targets (Aaskoven, 2016: 319), and even direct imposition/removal of subnational hiring freezes (Grembi et al., 2016: 6). ${ }^{10}$ Consequently, the political ideology and/or electoral incentives of the central government should also be able to affect subnational employment levels. Thus, I have chosen to use general government employment level as the key dependent variable.

The measure of left-wing government is a dummy indicating whether the chief executive is from a left-wing party. The data comes from the Database of Political Institutions (Beck et al., 2001). A pure dummy on government partisanship obviously does not capture potential ideological differences between left-of-centre parties, either between or within countries, but the opportunistic reason for increasing public employment in order to increase potential vote share would hold for both moderate and more far-left parties. To test for the potential effect of differences in ideology

\footnotetext{
${ }^{10}$ See also discussion in Cahan (2019: 124-125; 130).
} 
intensity, however, a robustness test is conducted where the left-wing chief executive dummy is replaced by a continuous measure of the ideology of the chief executive from the Manifesto Project (Volkens et al., 2015). As a further robustness test, the core results are also rerun with the percentage of left-wing cabinet members from the Comparative Political Dataset (Armingeon et al., 2015) instead of a left-wing chief executive dummy, in order to assess the potential effect of the ideological makeup of the government rather than just the ideology of the chief executive.

As another political explanatory variable, I use a dummy for whether there is an election with a potentially decisive effect for the incumbent government in the current year. This is coded as parliamentary elections for all countries but France and the United States, where it is coded as presidential elections. This variable is included to control for a potential independent electoral cycle in public employment, as well as to test Hypothesis 2. Following an approach used by Brender and Drazen (2005: 1282-1283) and Katsimi and Sarantides (2012: 41), I distinguish between exogenous and endogenous elections later in the analysis. I code an exogenous election year as an election in the year in which the term for the current parliament (or president for France and the United States) expires. Endogenous election years are those falling in the years where the term does not formally expire. The data for the election variables is from the Database of Political Institutions.

Economic control variables include GDP per capita in 1,000 constant US dollars to control for the potential Wagner's Law effect on the size of the public sector, including public employment, which states that higher levels of economic development will increase the demand for services provided by the public sector (Boix, 2001: 1-6). I also include the GDP growth rate to control for a dynamic version of the Wagner's Law effect as well as to hold the general state of the economy constant, which could affect the denominator of the public employment as a share of total labour force.

The unemployment rate is also added as a control variable. Earlier research has found that unemployment has an impact on public employment levels (Murrell, 1985). Controlling for unemployment might also capture general labour market dynamics, which might in turn influence the denominator of the public employment as a share of total labour force variable. Particularly 
given that the classical partisan theory also expects left-wing government control to affect the unemployment rate (Hibbs, 1977), this is a vital control.

As a final economic control variable, I include general government spending (expenditure) as a percentage of GDP. While this variable naturally includes wage expenditures for public employees, one might plausibly claim that left-wing governments would have an incentive to increase public employment, even given the general size of the public sector, in order to increase potential vote share. This could be achieved by spending more on public employment relative to other types of public spending, and/or given the same level of public wage expenditures to maintain more - and relatively lesser paid - public sector workers than a smaller number of better paid public sector workers. Previous research does indeed suggest that left-wing parties tend to favour more public employment over higher public wages in this trade-off (Blais et al., 1997: 163). We would also expect left-wing governments (as opposed to centrist and right-wing governments) to prefer providing public services directly through publicly employed personnel, rather than through vouchers and choice schemes within, for example, health and education, as suggested by previous research (Jensen, 2011). These strategies would potentially leave public spending levels unchanged, but cause greater levels of public employment. Furthermore, unlike public transfer spending, the level and eligibility of which is usually determined by law, increasing or decreasing public employment is usually more at the discretion of an incumbent government, since its ministers can at least partly influence personnel decisions, including central government hiring and layoffs. The sources for all of the economic control variables are the OECD databases. The exception is the data for government spending for New Zealand, where the data was taken from an online version of the IMF World Economic Outlook database. Table 1 presents the descriptive statistics for the dataset, while a correlation matrix of all the independent variables from the main analysis can be found in appendix A. ${ }^{11}$

\footnotetext{
${ }^{11}$ Table 1 also contains descriptive statistics for alternative measures of left-wing government and additional control variables used in the later robustness tests.
} 
Table1: Descriptive Statistics.

\begin{tabular}{|c|c|c|c|c|c|}
\hline Variable & Mean & Std. Dev. & Min & Max & Observations \\
\hline Public employment & 18.71 & 6.73 & 6.64 & 37.06 & 273 \\
\hline Left-wing chief executive (dummy) & 0.45 & 0.50 & 0 & 1 & 273 \\
\hline Left-right (rile) placement of the chief executive's party & 36.41 & 39.55 & 0 & 100 & 273 \\
\hline Percentage of left-wing cabinet members & -0.14 & 17.18 & -38.18 & 48.46 & 267 \\
\hline GDP per capita $(1,000)$ & 33.46 & 9.42 & 18.10 & 72.57 & 273 \\
\hline Expenditure & 44.46 & 7.00 & 31.15 & 65.50 & 270 \\
\hline Unemployment & 6.99 & 3.39 & 2.1 & 23 & 273 \\
\hline GDP growth & 2.65 & 2.47 & -6.40 & 10.80 & 273 \\
\hline Chief executive election (dummy) & 0.28 & 0.45 & 0 & 1 & 273 \\
\hline Exogenous election & 0.20 & 0.40 & 0 & 1 & 273 \\
\hline Endogenous election & 0.08 & 0.27 & 0 & 1 & 273 \\
\hline Tax revenue as percentage of GDP & 38.45 & 6.56 & 23.76 & 51.53 & 236 \\
\hline Minority government & 0.22 & 0.41 & 0 & 1 & 273 \\
\hline Single-party government & 0.34 & 0.48 & 0 & 1 & 273 \\
\hline
\end{tabular}

\section{Estimation}

The empirical test of the effect of left-wing partisanship on public employment consists of a series of ordinary least squares (OLS) regressions with country-fixed effects. ${ }^{12}$ Country-fixed effects enables me to hold constant potential time-invariant factors which might be endogenously related both to a higher prevalence of left-wing government control and a higher level of public employment, thus minimizing issues with omitted variable bias, especially given the use of the other time-varying control variables ${ }^{13}$ (Wooldridge, 2006: 95-97). The estimation is shown in

${ }^{12}$ To estimate an unbiased effect of left-wing partisanship on public employment, it requires that left-wing partisanship is not in itself partly determined by public employment levels (Wooldridge, 2006: 557-559), which could be an issue in this case. However, with the use of country-fixed effects this simultaneity problem should be less severe (Wooldridge, 2006: 571). Furthermore, the election (especially the exogenous election) variable and the interaction between election and left-wing partisanship should not suffer from this problem, as a high public employment level should not be able to affect the occurrence of an election in the year the government's term formally expires.

13 This of course rests on the assumption that these control variables are reasonable well-measured and/or act as reasonable unbiased proxies for the underlying endogenous concepts, such as demand for public services, (Wooldridge, 2006: 310-315). However, as argued "Variables and data sources" section, this is likely to be the case. 
Equation 1, with countries indexed by $i$ and years by $t$, where $\mathrm{Y}$ is the level of public employment as a percentage of total labour force in country $i$ at time $t$. Leftwing is the dummy for whether the chief executive is from a left-wing party. Election is a dummy for whether there is an election which is potentially decisive for the executive - in country $i$ in year $t$. It is included in some of the later specifications. In order to test Hypothesis 2, the left-wing and election dummies are interacted in some later specifications. $\mathrm{X}$ is the vector of economic controls, $\eta_{i}$ is the country-fixed effects, and $\epsilon_{i t}$ the error term. In the main specifications, year-fixed effects denoted by $\tau_{\mathrm{t}}$ are added to the specifications in order to address issues of a time trend in the level of public employment over the analysed period.

$$
Y_{i t}=\beta_{1} \text { leftwing }_{i t}+\beta_{2} \text { Election }_{i t}+\beta_{3} \text { leftwing }_{i t} \text { Election }_{i t}+\beta_{4} X_{i t}+\eta_{i}+\tau_{t}+\epsilon_{i t}
$$

In order to address autocorrelation issues, ${ }^{14}$ standard errors are clustered at the country level (Angrist and Pischke, 2009: 315-319).

\section{Results: Partisan effect on public employment}

The main results for the statistical analyses can be found in Table 2, where the pure ideological effect of left-wing government control on public employment levels is analysed. Column 1 reports the main results from the fixed-effect regressions with full controls. The coefficient for the leftwing chief executive dummy has the opposite sign than expected, and it is not close to being statistically significant. When accounting for country-specific unobservable factors, there seems to be no significant association between left-wing government control and level of public employment. The exclusion of the various control variables one by one, which can be found in appendix B, does not make the left-wing chief executive dummy statistically significant. Of the control variables, only general government expenditure and GDP per capita seem to be statistically significantly associated with the level of public employment. ${ }^{15}$ Thus, there seems to be no

\footnotetext{
${ }^{14}$ A Wooldridge test does indeed suggest issues of autocorrelation in the subsequent estimations.

${ }^{15}$ However, a VIF test reveals a great deal of multicollinearity for the control variables: GDP per capita $(\mathrm{VIF}=49.45)$, GDP growth rate $(\mathrm{VIF}=4.07)$, unemployment $(\mathrm{VIF}=5.72)$, general government expenditure ( $\mathrm{VIF}=11.83$ ). If general government expenditure and GDP per capita is removed from the analysis, the null effect of the left-wing chief executive election remains, and the
} 
independent electoral cycle in public employment judging from these results. This stands in contrast to subnational level findings (Tepe and Vanhuyesse, 2009, 2013; Dahlberg and Mörk, 2011; Bee and Moulton, 2015). But it is more in accordance with many comparative studies of electoral budget cycles, which find that non-contingent cycles in public expenditures (and thereby potentially also public employment) are not usually found in developed consolidated democracies like OECD countries (Brender and Drazen, 2005; Klomp and De Haan, 2013).

Table 2: Partisan Effect and Partisan-Electoral Effect on Public Employment.

\begin{tabular}{|c|c|c|c|c|c|}
\hline & 1 & 2 & 3 & 4 & 5 \\
\hline Left-wing chief executive (dummy) & $\begin{array}{c}-0.083 \\
(0.177)\end{array}$ & $\begin{array}{c}-0.153 \\
(0.179)\end{array}$ & $\begin{array}{c}-0.148 \\
(0.179)\end{array}$ & $\begin{array}{l}-0.070 \\
(0.173)\end{array}$ & $\begin{array}{c}-0.143 \\
(0.176)\end{array}$ \\
\hline Election & $\begin{array}{c}0.041 \\
(0.056)\end{array}$ & $\begin{array}{c}-0.071 \\
(0.067)\end{array}$ & - & - & - \\
\hline Left-wing chief executive $\times$ election & - & $\begin{array}{c}0.240 \\
(0.135)^{*}\end{array}$ & - & - & - \\
\hline Exogenous election & - & - & $\begin{array}{c}-0.159 \\
(0.086)^{*}\end{array}$ & - & $\begin{array}{c}-0.151 \\
(0.079)^{*}\end{array}$ \\
\hline Endogenous election & - & - & - & $\begin{array}{c}0.255 \\
(0.291)\end{array}$ & $\begin{array}{c}0.230 \\
(0.286)\end{array}$ \\
\hline Left-wing chief executive (dummy) $\times$ exogenous election & - & - & $\begin{array}{c}0.338 \\
(0.167)^{*}\end{array}$ & - & $\begin{array}{c}0.345 \\
(0.165)^{* *}\end{array}$ \\
\hline Left-wing chief executive (dummy) $\times$ endogenous election & - & - & - & $\begin{array}{l}-0.154 \\
(0.336)\end{array}$ & $\begin{array}{c}-0.087 \\
(0.333)\end{array}$ \\
\hline GDP per capita (1000) & $\begin{array}{c}0.236 \\
(0.122)^{*}\end{array}$ & $\begin{array}{c}0.237 \\
(0.121)^{*}\end{array}$ & $\begin{array}{c}0.237 \\
(0.120)^{*}\end{array}$ & $\begin{array}{c}0.236 \\
(0.122)^{*}\end{array}$ & $\begin{array}{c}0.237 \\
(0.121)^{*}\end{array}$ \\
\hline GDP growth rate & $\begin{array}{c}-0.003 \\
(0.069)\end{array}$ & $\begin{array}{c}0.000 \\
(0.071)\end{array}$ & $\begin{array}{l}-0.000 \\
(0.071)\end{array}$ & $\begin{array}{l}-0.003 \\
(0.070)\end{array}$ & $\begin{array}{c}0.001 \\
(0.071)\end{array}$ \\
\hline Unemployment & $\begin{array}{c}-0.063 \\
(0.058)\end{array}$ & $\begin{array}{c}-0.063 \\
(0.058)\end{array}$ & $\begin{array}{c}-0.061 \\
(0.058)\end{array}$ & $\begin{array}{l}-0.065 \\
(0.058)\end{array}$ & $\begin{array}{l}-0.063 \\
(0.058)\end{array}$ \\
\hline Expenditure & $\begin{array}{c}0.117 \\
(0.047)^{* *}\end{array}$ & $\begin{array}{c}0.117 \\
(0.047)^{* *}\end{array}$ & $\begin{array}{c}0.115 \\
(0.046)^{* *}\end{array}$ & $\begin{array}{c}0.117 \\
(0.047)^{* *}\end{array}$ & $\begin{array}{c}0.116 \\
(0.046)^{* *}\end{array}$ \\
\hline $\begin{array}{l}\text { Country-fixed effects } \\
\text { Year-fixed effects }\end{array}$ & $\begin{array}{l}\text { Yes } \\
\text { Yes }\end{array}$ & $\begin{array}{l}\text { Yes } \\
\text { Yes }\end{array}$ & $\begin{array}{l}\text { Yes } \\
\text { Yes }\end{array}$ & $\begin{array}{l}\text { Yes } \\
\text { Yes }\end{array}$ & $\begin{array}{l}\text { Yes } \\
\text { Yes }\end{array}$ \\
\hline Within R-squared & 0.431 & 0.434 & 0.436 & 0.433 & 0.438 \\
\hline Number of countries & 22 & 22 & 22 & 22 & 22 \\
\hline $\mathrm{N}$ & 270 & 270 & 270 & 270 & 270 \\
\hline
\end{tabular}

negative GDP growth coefficient becomes statistically significant at the $\mathrm{p}<0.1$ level. The results for the left-wing chief executive and the interaction between the election variables and the left-wing chief executive dummy are also largely similar if all the control variables are removed from the analysis. Results are available upon request. 
Evidence of an independent partisan effect on the level of public employment seems lacking. The question might arise, however, as to whether the left-wing dummy does fully capture the ideological differences between right and left-wing parties and between moderate and less moderate left-wing parties. In order to address this concern, the models are rerun using the continuous rile indicator of left-right alignment for the chief executive's party from the well-known Manifesto Project's database (Volkens et al., 2015). See Appendix C for the results using the rile ${ }^{16}$ indicator. This indicator takes a higher value the more right wing the party is. Using this continuous measure of the ideology of the chief executive does not change the results for the independent effect of left-wing government on the level of public employment.

As an additional test for an independent partisan effect, the left-wing chief executive variable is replaced in Appendix D by a variable measuring the percentage of cabinet members from left-wing parties ${ }^{17}$ to test whether the partisan makeup of the government (rather than the partisanship of the chief executive) might matter for public employment levels. Using this variable captures situations in which left-wing parties are in a coalition government with centrist or right-wing parties ${ }^{18}$ and would test whether the effect of left-wing government control on public employment is contingent on the extent to which left-wing parties control the government without non-left coalition partners. In line with the previous results, however, the share of left-wing cabinet members has no statistically significant effect on public employment levels. There seems to be weak evidence in favour of an effect of left-wing government control on public employment. ${ }^{19}$

${ }^{16}$ Replacing the rile indicator with the Manifesto Project's welfare indicator, which measures parties' positions on redistribution and welfare state expansion, even suggests a negative effect on public employment when the party of the chief executive scores higher (more left-wing) on this indicator. Results are available upon request.

${ }^{17}$ Data is from Comparative Political Dataset (Armingeon et al., 2015).

${ }^{18}$ As in the case of the German grand coalition.

${ }^{19}$ As noted by Blais et al. (1993), the effects of government partisanship on public policy might take some time to materialise. However, lagging the left-wing government variable one year does not change the results. The results are also similar if the control variables are lagged one year. Results are available upon request. 
In short, once country-level unobserved effects are accounted for, there seems to be no statistically robust effect of left-wing control of government on public employment levels. These findings are at odds with the ideology-based mechanism for the partisan effect of public employment, which forms the basis of Hypothesis 1, and some of the empirical studies of the effect of partisanship surveyed in the beginning of this article. If ever there was a pure ideological partisan effect on public employment in developed democracies, it has either disappeared or weakened in recent decades to a level where it is no longer statistically detectable, which also seems to have been the case for other potentially partisan-affected areas of fiscal policy (Cusack, 1999).

The strictly ideological view of the impact of left-wing governments on public employment stated in Hypothesis 1 does not seem to find any support among the 22 OECD countries in recent decades. However, one might speculate whether the potential effect of left-wing partisanship would be strictly non-contingent on other political factors, as the previous tests assume. If left-wing governments are motivated not by ideological, but by opportunistic voter maximising strategies when deciding public personnel policies, we would, in accordance with Hypothesis 2, not expect a potential effect of partisanship on the level of public employment to be even across the electoral cycle. On the contrary, we would expect a re-election-concerned left-wing government to target resources towards increasing public employment when the need to secure a larger proportion of leftleaning voters (e.g. public employees) is greater, which is the case in election years. In order to address these issues and test Hypothesis 2, I interact the left-wing dummy with the election dummy. Column 2 in Table 2 presents evidence in favour of the election-contingent effect of left-wing partisanship on public employment. The interaction between left-wing chief executive and an election is statistically significant at the 0.1 level. The effect size is furthermore non-trivial. In the case an election year, an incumbent left-wing chief executive increases public employment as a percentage of total labour force with about 0.1 percentage points, which in the United States would translate into 150,000 extra public employees in the year 2010. This result shows support for Hypothesis 2, and provides indication of the existence of a combined partisan-electoral cycle in public employment within the OECD countries.

While no pure partisan effect on public employment can be detected among the OECD countries in the years 1995-2010, left-wing governments seem to increase public employment in election years. The empirical findings above seem to suggest that, in terms of public employment, left-wing parties 
time their efforts in catering to and increasing one of their core constituencies - public employees to elections, a finding which is in line with the opportunistic vote-maximising argument from the theoretical section. ${ }^{20}$

However, as elections in most OECD countries can and often are held before the law-determined term expires, the inherent endogeneity of election years in most OECD countries could be an issue for the interpretation of the results above. To tackle this issue, I employ an approach advanced by, among others, Brender and Drazen (2005: 1282-1283) and Katsimi and Sarantides (2012: 41), distinguishing between elections held in years where the incumbent's term expires (exogenous election) and between elections held in a year where the term does not formally expire (endogenous election). In Columns 3, 4 and 5 in Table 2, the election dummy is replaced with dummies for exogenous elections and endogenous elections. In Column 3, the interaction between exogenous elections and a left-wing incumbent seems to have the expected positive effect on the level of public employment, which is statistically significant at a 0.1 level. The size effect of the interaction also increases in comparison with Column 2. In an election held in the year in which the incumbent's term formally expires, a left-wing incumbent would result in an increase in the level of public employment to total labour force of 0.19 percentage points. In France, for example, this increase would translate into roughly an additional 50,000 public employees in 2002. The effect on public employment levels of a foreseen election under a left-wing incumbent is thus substantial.

The constituting exogenous election dummy has a negative and statistically significant effect on public employment levels, which suggests that in foreseen election years, non-left governments actually decrease the number of public employees as a share of total employment. Presumably, they do so because centrist and especially right-wing governments' core voters are more likely to be privately rather than publically employed citizens. These governments might thus seek to decrease

${ }^{20}$ It is worth mentioning that the implementation of this increase in public employment might take both programmatic and/or clientelistic forms (Hicken, 2011; Robinson and Verdier, 2013). At least in some OECD countries, clientelistic relationships between political parties and public employees might be prevalent. These clientelistic relationships might also be especially relevant in election years, as some empirical evidence suggests (Stolfi and Hallerberg, 2015). 
the number of public employees, since it is well known that public employees are generally leftwing core supporters. Alternatively, right-wing and centrist governments might - at least in election years - increase the relative level of private employment while leaving public employment at similar or slightly lower levels, through policies such as increased spending on public procurement and/or an increase in public spending on healthcare provided by private health care providers (Jensen, 2011). These are alternative political budget cycles strategies, ${ }^{21}$ which might decrease the level of public employment relative to total employment.

In Column 4 of Table 2, the election dummy used is the endogenous election dummy. In this specification, the interaction between a left-wing incumbent and the endogenous election does not have a statistically significant effect on the level of public employment. The results are similar, and the interaction between exogenous election and left-wing chief executive even reaches a higher level of statistical significance, when the exogenous and endogenous election interactions are analysed together in Column $5 .^{22}$ The potential effect on public employment expansions of the coincidence of a left-wing incumbent and an election is apparently limited to election years in which the incumbent can be sure elections will be held - potentially as public personnel decisions take time to implement. These findings further strengthen the interpretation that left-wing incumbents time hiring/public personnel decisions to elections so as to secure a higher level of core supporters rather than engaging in electoral surfing (Kayser, 2005), when levels of public employment peak for other reasons. The effect of left-wing governments on public employment is thus variable over the course of the electoral cycle.

While no independent effect of left-wing partisanship can be detected on the level of public employment, left-wing governments facing elections seem to increase the number of public employees relative to the total number of employees. This combined partisan-opportunistic electoral cycle in public employment might be one of the causes of public employment fluctuations in and

\footnotetext{
${ }^{21}$ There is no reason to believe that right-wing governments should be less likely to engage in election-year fiscal manipulation (Alt and Lassen, 2006a).

${ }^{22}$ In this case, non-election years are the baseline category.
} 
among developed democracies. The results further confirm one of the central findings in the recent literature on political budget cycles, about how political cycles in policy instruments are often contingent on mediating political factors (Franzese, 2002: 406-412; Alt and Rose, 2007; Dubois, 2016: 244-248), including government partisanship (Aksoy, 2018). In the case of public employment, partisan effects seem to be contingent on the electoral calendar and vice versa.

\section{Robustness checks}

In order to test the robustness of the partisan-electoral cycle in public employment, I redo the key estimation from Table 2, Column 3, to test the robustness of the effect of the interaction between an exogenous election and a left-wing chief executive on public employment. These additional tests are reported in Table 3. I first add a control for the level of tax revenue as a percentage of GDP, to check whether the partisan-electoral effect on public employment levels instead reflects differences in election-year taxation policies between left-wing governments and other governments. While the inclusion of this variable, which is in itself not a statistically significant predictor of public employment levels, decreases the effect size of the left-wing and exogenous election interaction variable slightly, this interaction remains statistically significant and of a substantial size effect. In Columns 2 and 3, I then control for government characteristics and include a dummy for whether the government is a minority government and whether it is a single-party government based on data from the Database of Political Institutions. The inclusion of these variables does not change the statistical significance or size effect of the exogenous election/left-wing chief executive interaction in any substantial way. The minority government dummy has no statistically significant effect on the level of public employment, while the single-party dummy also seems to have no statistically significant effect on public employment levels.

To test whether this potential effect of a single-party government mediates the partisan-electoral cycle, in Column 4 the single-party dummy is interacted with both the exogenous election and the left-wing chief executive dummy. While there is still substantial and significant evidence in favour of a partisan-electoral cycle in public employment, it does not seem to be affected by whether the left-wing party in government is the sole government party, since the three-variable interaction between left-wing chief executive, exogenous election, and single-party government is far from any level of statistical significance. 
As additional robustness tests, I investigate whether the results are driven by the anomalies of certain countries. First I remove Switzerland from the analysis in Column 5. Due to the special Swiss government structure, Switzerland experiences no incidence of left-wing chief executive, and concerns might be raised that the potential anomaly of Switzerland ${ }^{23}$ drives some of the results. The exclusion of Switzerland only increases the statistical significance level of the left-wing chief executive and exogenous election interaction. In Column 6, I remove Greece from the sample. Greek politics have historically been prone to clientelism, often taking the form of public employment, ${ }^{24}$ which could raise concerns about whether the above effects only capture features of Greek politics. While the removal of Greece lowers the coefficient size of the exogenous election and left-wing chief executive variable and makes it lose its statistical significance, the coefficient is still close to being statistically significant at the $\mathrm{p}<0.10$ level, and is still of a substantial effect size. While Greece clearly seems to provide a lot of examples of incumbent left-wing governments increasing public employment in election years, ${ }^{25}$ it is clearly not the only country driving the results. $^{26}$

As a final robustness test, I conduct a larger sample restriction. Given that the partisan-electoral effect on public employment is only valid for election years, where the election is scheduled and therefore exogenous, concerns might arise that the results are instead capturing systematic differences between countries that experience/allow for endogenous elections versus those that do not. ${ }^{27}$ In order to address this concern in Column 7 , I remove all countries from the analysis that do not experience any endogenous elections during the analysed time period. ${ }^{28}$ However, the exogenous election and left-wing chief executive variable retains its statistical significance level and only increases in effect size. The results of the robustness tests lend substantial support for the existence of a partisan-electoral cycle in public employment, which seem to be driven by

\footnotetext{
${ }^{23}$ Switzerland also generally has below panel-average levels of public employment.

${ }^{24}$ See Matakos and Xefteris (2016).

${ }^{25}$ Maybe due to Greece's low levels of fiscal transparency (Alt and Lassen, 2006b).

${ }^{26}$ Similar results are found, if each of the other countries is removed one at the time. No single country thus seems to drive the results above. Results are available upon request.

27 The United States offers an obvious example.

${ }^{28}$ Finland, France, Luxembourg, New Zealand, Norway, Sweden, Switzerland, and United States.
} 
opportunistic motivation to increase the share of core voters for left-wing parties when they are needed. ${ }^{29}$

${ }^{29}$ In appendices $\mathrm{C}$ and $\mathrm{D}$, the election variables are also interacted with the alternative measures of government ideology. However, here the interactions are insignificant which further suggests that the partisan-electoral effect is not about ideology intensity and thus seems to be opportunistic rather than ideological. 
Table 3. Robustness Checks.

\begin{tabular}{|c|c|c|c|c|c|c|c|}
\hline & $\begin{array}{l}\text { Control for tax } \\
\text { revenue }\end{array}$ & Minority government & $\begin{array}{l}\text { Single-party } \\
\text { government }\end{array}$ & $\begin{array}{l}\text { Single-party } \\
\text { government } \\
\text { interaction }\end{array}$ & $\begin{array}{l}\text { Excluding } \\
\text { Switzerland }\end{array}$ & Excluding Greece & $\begin{array}{c}\text { Excluding countries } \\
\text { without endogenous } \\
\text { elections }\end{array}$ \\
\hline Left-wing chief executive (dummy) & $\begin{array}{l}-0.088 \\
(0.164)\end{array}$ & $\begin{array}{l}-0.205 \\
(0.202)\end{array}$ & $\begin{array}{l}-0.201 \\
(0.200)\end{array}$ & $\begin{array}{l}-0.059 \\
(0.218)\end{array}$ & $\begin{array}{l}-0.154 \\
(0.179)\end{array}$ & $\begin{array}{l}-0.066 \\
(0.170)\end{array}$ & $\begin{array}{l}-0.353 \\
(0.182)^{*}\end{array}$ \\
\hline Exogenous election & $\begin{array}{l}-0.199 \\
(0.099)^{*}\end{array}$ & $\begin{array}{l}-0.165 \\
(0.090)^{*}\end{array}$ & $\begin{array}{l}-0.157 \\
(0.083)^{*}\end{array}$ & $\begin{array}{c}-0.163 \\
(0.077)^{* *}\end{array}$ & $\begin{array}{l}-.0 .187 \\
(0.091)^{*}\end{array}$ & $\begin{array}{l}-0.126 \\
(0.082)\end{array}$ & $\begin{array}{l}-0.147 \\
(0.092)\end{array}$ \\
\hline $\begin{array}{l}\text { Left-wing chief executive (dummy) } \times \\
\text { exogenous election }\end{array}$ & $\begin{array}{c}0.300 \\
(0.169)^{*}\end{array}$ & $\begin{array}{c}0.318 \\
(0.173)^{*}\end{array}$ & $\begin{array}{c}0.325 \\
(0.159)^{*}\end{array}$ & $\begin{array}{c}0.384 \\
(0.166)^{* *}\end{array}$ & $\begin{array}{c}0.365 \\
(0.171)^{* *}\end{array}$ & $\begin{array}{c}0.262 \\
(0.159)\end{array}$ & $\begin{array}{c}0.371 \\
(0.181)^{*}\end{array}$ \\
\hline GDP per capita $(1,000)$ & $\begin{array}{c}0.250 \\
(0.116)^{* *}\end{array}$ & $\begin{array}{c}0.248 \\
(0.111)^{* *}\end{array}$ & $\begin{array}{c}0.232 \\
(0.123)^{*}\end{array}$ & $\begin{array}{l}0.226 \\
(0.126)^{*}\end{array}$ & $\begin{array}{l}0.237 \\
(0.121)^{*}\end{array}$ & $\begin{array}{l}0.226 \\
(0.122)^{*}\end{array}$ & $\begin{array}{c}0.086 \\
(0.102)\end{array}$ \\
\hline GDP growth rate & $\begin{array}{l}-0.058 \\
(0.067)\end{array}$ & $\begin{array}{l}-0.005 \\
(0.064)\end{array}$ & $\begin{array}{l}-0.007 \\
(0.070)\end{array}$ & $\begin{array}{l}-0.007 \\
(0.069)\end{array}$ & $\begin{array}{c}0.003 \\
(0.074)\end{array}$ & $\begin{array}{l}-0.021 \\
(0.068)\end{array}$ & $\begin{array}{c}0.021 \\
(0.051)\end{array}$ \\
\hline Unemployment & $\begin{array}{l}-0.108 \\
(0.059)^{*}\end{array}$ & $\begin{array}{l}-0.063 \\
(0.056)\end{array}$ & $\begin{array}{l}-0.057 \\
(0.059)\end{array}$ & $\begin{array}{l}-0.056 \\
(0.058)\end{array}$ & $\begin{array}{l}-0.062 \\
(0.059)\end{array}$ & $\begin{array}{l}-0.053 \\
(0.061)\end{array}$ & $\begin{array}{c}-0.115 \\
(0.051)^{* *}\end{array}$ \\
\hline Expenditure & $\begin{array}{c}0.105 \\
(0.041)^{* *}\end{array}$ & $\begin{array}{c}0.122 \\
(0.044)^{* *}\end{array}$ & $\begin{array}{c}0.114 \\
(0.047)^{* *}\end{array}$ & $\begin{array}{c}0.108 \\
(0.046)^{* *}\end{array}$ & $\begin{array}{c}0.118 \\
(0.047)^{* *}\end{array}$ & $\begin{array}{c}0.098 \\
(0.043)^{* *}\end{array}$ & $\begin{array}{c}0.094 \\
(0.042)^{* *}\end{array}$ \\
\hline Tax revenue as percentage of GDP & $\begin{array}{c}0.046 \\
(0.084)\end{array}$ & - & - & - & - & - & - \\
\hline Minority government & - & $\begin{array}{l}0.406 \\
(0.246)\end{array}$ & - & - & - & - & - \\
\hline Single-party government & - & - & $\begin{array}{c}0.304 \\
(0.233)\end{array}$ & $\begin{array}{c}0.541 \\
(0.370)\end{array}$ & - & - & - \\
\hline $\begin{array}{l}\text { Left-wing chief executive (dummy) } \times \text { single- } \\
\text { party government }\end{array}$ & - & - & - & $\begin{array}{l}-0.442 \\
(0.455)\end{array}$ & - & - & - \\
\hline Exogenous election $\times$ single-party government & - & - & - & $\begin{array}{c}0.040 \\
(0.204)\end{array}$ & - & - & - \\
\hline $\begin{array}{l}\text { Left-wing chief executive (dummy) } \times \\
\text { exogenous election } \times \text { single-party government }\end{array}$ & - & - & - & $\begin{array}{c}-0.142 \\
(0.331)\end{array}$ & - & - & - \\
\hline Country-fixed effects & Yes & Yes & Yes & Yes & Yes & Yes & Yes \\
\hline Year-fixed effects & Yes & Yes & Yes & Yes & Yes & Yes & Yes \\
\hline Adjusted R-squared & 0.456 & 0.455 & 0.440 & 0.449 & 0.432 & 0.449 & 0.483 \\
\hline Number of countries & 22 & 22 & 22 & 22 & 21 & 21 & 16 \\
\hline Number of observations & 235 & 270 & 270 & 270 & 265 & 256 & 204 \\
\hline
\end{tabular}

Dependent variable is public employment as a share of total labour force. OLS-estimates with standard errors clustered by country in parentheses.

$* \mathrm{p}<0.10$.

$* * \mathrm{p}<0.05$.

$* * * \mathrm{p}<0.01$ 


\section{Discussion and conclusion}

Questions of partisan differences in the conduct of public policy continue to be at the forefront of research in political science and political economy. Public employment would be an obvious area for partisan effects on public policies. This article has explored the potential partisan effect of the level of public employment in a panel of 22 OECD countries. The results show little independent effect of a left-wing controlled government on the level of public employment. However, there is some evidence that the coincidence of a left-wing government and an election year increases the share of public employment in the total labour force, although even here there is some uncertainty associated with this result. These findings suggest an attempt by a left-wing incumbent government to increase and mobilise one of left-wing parties' core support groups in most developed democracies: public employees. The results only hold for elections held in years in which the incumbent government's term expires, which further suggests that left-wing incumbents purposefully time expansions of public employment to years when they need electoral support. The results suggest that the partisan influence of public employment is caused by opportunistic rather than ideological motivations and proposes the existence of a combined partisan-opportunistic electoral cycle in public employment among developed democracies.

These findings seem to illuminate the behaviour of some incumbent left-wing parties and politicians, both during and between election years. In March 2004, for example, the incumbent left-wing PASOK party in Greece faced a legislative election after 11 years in office. Facing unfavourable opinion polls, the PASOK government seems to have responded by increasing public employment significantly. The number of public employees, which had already grown during most of the PASOK years, grew by about 8 percent from 2003 to 2004, a much higher growth rate than in any of the preceding years. While PASOK ultimately lost the election, the prospect of electoral loss seems to have induced them to increase the number of their potential core voters. A similar strategy seems to have been pursued by the Austrian Social Democratic Party in the 1999 national elections, where public employment increased from 1997 to 1998, and even further from 1998 to 1999, after a significant decrease in the beginning of the electoral term. The results and theoretical arguments made in this article cast light on this cyclical behaviour of public employment under left-wing government control, suggesting that the concern of left-wing governments for the level of public 
employment seems to be mainly driven by an incentive to mobilise and increase the number of core voters when they are most needed. This perspective might also explain why the issue of public employment and the conditions for public employees often features prominently in the electoral campaigns of left-wing parties - as with French President Francois Hollande's 2012 campaign promise to hire 60,000 additional teachers - but are sometimes downplayed or prioritised less when left-wing parties are actually in office. Here, left-of-centre governments might even pursue policies that directly hurt public employees, as was the case with the Danish centre-left government's reform of the working hours of Danish teachers in 2013 in the middle of the Danish electoral calendar. If these cases represents a general trend, as the results of this article suggest, it has significant implications for public sector stakeholders in developed democracies, including public employees themselves. Having left-wing parties as a champion of public sector interests, at least within the public employment area, is apparently heavily dependent on the electoral incentives these parties face rather than a staunch ideological commitment. An insight advocates and lobbyists (including public sector unions) for both higher and lower levels of public employment should bear in mind (if they do not do so already).

The results of this article also have implications of the wider study of partisan politics and electoral cycles in public policy measure, including those beyond the pure fiscal policy aggregates (Aaskoven and Lassen, 2017). This article suggests that in some policy areas, neither government ideology nor election occurrence might in themselves produce any policy deviations. However, the combination of these two factors might produce substantial cycles in public policy measures - see Aksoy (2018). Future research could expand and explore this combined partisan-opportunistic cycle further, and explore more dynamically the potential relationship between the ideological orientation of the government, electoral incentives, and public policies. Given that the existence of electoral cycles in most developed democracies seems to be contingent on institutional, economic, and political factors (Alt and Lassen, 2006b; Klomp and de Haan, 2013; Aaskoven, 2016), exploring which factors raise or depress this potential partisan-opportunistic electoral cycle in public employment, and other policy measures, could be an interesting area of research. Future research might also expand these issues to subnational units, such as municipalities and federal states. Furthermore, given that there seem to be differences in left-partisan alignments among different types of public employees in developed democracies (Tepe, 2012: 250), perhaps we should not 
expect the combined effect of elections and left-wing partisanship to be the same for different types of public employees. Finally, this article has investigated the partisan-electoral causes of public employment fluctuations, but not whether election-year increases in public employment yield any electoral benefits for incumbent left-wing governments or incumbent governments in general. Future research could fruitfully address these issues. 


\section{References}

Aaskoven L (2016) Fiscal transparency, elections and public employment: evidence from the OECD. Economics and Politics 28: 317-341.

Aaskoven L and Lassen DD (2017) Political Budget Cycles. In: Thompson WR (ed) Oxford Research Encyclopaedia of Politics. Oxford: Oxford University Press.

Aksoy D (2018) Electoral and Partisan Cycles in Counterterrorism. Journal of Politics 80(4): $1239-1253$.

Alesina A, Baqir R and Easterly W (2000) Redistributive public employment. Journal of Urban Economics 48: 219-241.

Alesina A, Perotti R, Tavares J, Obstfeld M and Eichengreen B (1998) The Political Economy of Fiscal Adjustments. Brookings Papers on Economic Activity No. 1 (1998): 197-266.

Alesina A, Roubini N and Cohen GD (1997) Political Cycles and the Macroeconomy. Cambridge, MA: The MIT Press

Alt JE and Lassen DD (2006a) Fiscal transparency, political parties, and debt in OECD countries. European Economic Review 50: 1403-1439.

Alt JE and Lassen DD (2006b) Transparency, political polarization, and political budget cycles in OECD countries. American Journal of Political Science 50: 530-550.

Alt JE and Rose S (2007) Context-conditional political budget cycles. In: Boix C and Stokes SC (eds) The Oxford Handbook of Comparative Politics. Oxford: Oxford University Press.

Angrist JD and Pischke J (2009) Mostly Harmless Econometrics: An Empiricist's Companion. Princeton: Princeton University Press.

Ansell B (2014) The political economy of ownership: housing markets and the welfare state. American Political Science Review 108: 383-402.

Anzia SF and Moe TM (2016) Do politicians use policy to make politics? The case of public-sector labor laws. American Political Science Review 110: 763-777. 
Armingeon K, Isler C, Knöpfel L, Weisstanner D and Engler S (2015) Comparative Political Data Set 1960-2013. Bern: Institute of Political Science, University of Berne.

Arndt C (2013) Social democracy's mobilization of new constituencies: the role of electoral systems. Party Politics 20: 778-790.

Beck T, Clarke G, Groff A, Keefer P and Walsh P (2001) New tools in comparative political economy: the database of political institutions. World Bank Economic Review 15: 165-176.

Bee AC and Moulton SR (2015) Political budget cycles in U.S. municipalities. Economics of Governance 16: 379-403.

Blais A, Blake D and Dion S (1990) The public/private cleavage in North America: the political behavior and attitudes of public sector employees. Comparative Political Studies 23: 381-403.

Blais A, Blake D and Dion S (1993) Do parties make a difference? Parties and the size of government in liberal democracies. American Journal of Political Science 37: 40-62.

Blais A, Blake D and Dion S (1997) Governments, Parties, and Public Sector Employees: Canada, United States, Britain, And France. Pittsburgh: University of Pittsburgh Press.

Boix C (2001) Democracy, development and the public sector. American Journal of Political Science 45: 1-17.

Brender A and Drazen A (2005) Political budget cycles in new versus established democracies. Journal of Monetary Economics 52: 1271-1295.

Cahan D (2019) Electoral cycles in government employment: Evidence from US gubernatorial elections. European Economic Review 111: 122-138.

Chang K, Kim Y, Tomljanovich M and Ying YH (2013) Do political parties foster business cycles? An examination of developed economies. Journal of Comparative Economics 41: 212-226.

Clark AE and Milcent C (2011) Public employment and political pressure: The case of French hospitals. Journal of Health Economics 30: 1103-1112.

Cox GW and McCubbins MD (1986) Electoral politics as a redistributive game. Journal of Politics 48: $370-389$. 
Cusack TR (1997) Partisan politics and public finance: changes in public spending in the industrialized democracies, 1955-1989. Public Choice 91: 375-395.

Cusack TR (1999) Partisan politics and fiscal policy. Comparative Political Studies 32: 464-486.

Cusack TR, Notermans T and Rein M (1989) Political-economic aspects of public employment. European Journal of Political Research 17: 471-500.

Dahlberg M and Johansson E (2002) On the vote-purchasing behavior of incumbent governments. American Political Science Review 96: 27-40.

Dahlberg M and Mörk E (2011) Is there an election cycle in public employment? Separating time effects from election year effects. CESifo Economic Studies 57: 480-498.

Dixit A and Londregan J (1996) The determinants of success of special interests in redistributive politics. Journal of Politics 58: 1132-1155.

Downs A (1957) An Economic Theory of Democracy. Boston: Addison-Wesley.

Dubois E (2016) Political business cycles 40 years after Nordhaus. Public Choice 166: 235-259.

Franzese RJ Jr (2002) Electoral and partisan cycles in economic policies and outcomes. Annual Review of Political Science 5: 369-421.

Frey BS and Schneider F (1978) An empirical study of politico-economic interaction in the United States. Review of Economics and Statistics 60: 174-183.

Gimpelson V and Treisman D (2002) Fiscal games and public employment: a theory with evidence from Russia. World Politics 54: 145-183.

Golden M and Min B (2013) Distributive politics around the world. Annual Review of Political Science 16: 73-99.

Grembi V, Nannicini T and Troiano U (2016) Do Fiscal Rules Matter? American Economic Journal: Applied Economics 8(3): 1-30.

Häusermann S, Picot G and Geering D (2013) Review article: rethinking party politics and the welfare state—recent advances in the literature. British Journal of Political Science 43: 221-240. 
Healy A and Lenz GS (2014) Substituting the end for the whole: why voters respond primarily to the election-year economy. American Journal of Political Science 58: 31-47.

Heckelman JC (2006) Another look at the evidence for rational partisan cycles. Public Choice 126: $257-274$.

Hibbs DA Jr (1977) Political parties and macroeconomic policy. American Political Science Review 71: 1467-1487.

Hicken A (2011) Clientelism. Annual Review of Political Science 14: 289-310.

Iversen T and Soskice D (2006) Electoral institutions and the politics of coalitions: why some democracies redistribute more than others. American Political Science Review 100: 165-181.

Iversen T and Rosenbluth F (2010) Women, Work and Politics: The Political Economy of Gender Inequality. New Haven: Yale University Press.

Jensen C (2011) Marketization via compensation: health care and the politics of the right in advanced industrialized nations. British Journal of Political Science 41: 907-926.

Katsimi M and Sarantides V (2012) Do elections affect the composition of fiscal policy in developed, established democracies? Public Choice 151: 325-362.

Kauder B, Potrafke N and Reischmann M (2016) Do politicians reward core supporter? Evidence from a discretionary grant program. European Journal of Political Economy 45: 39-56.

Kayser MA (2005) Who surfs, who manipulates? The determinants of opportunistic election timing and electorally motivated economic intervention. American Political Science Review 99: 17-27.

Klomp J and De Haan J (2013) Do political budget cycles really exist? Applied Economics 45: $329-341$.

Knutsen O (2005) The impact of sector employment on party choice: a comparative study of eight West European countries. European Journal of Political Research 44: 593-621.

Kurrild-Klitgaard P (2011) Kontraktpolitik, kulturkamp og ideologi 2001-2011. Økonomi \& Politik 84: 47-62. 
Larcinese V, Snyder JM Jr and Testa C (2013) Testing models of distributive politics using exit polls to measure voters' preferences and partisanship. British Journal of Political Science 43: $845-875$.

Lindbeck A and Weibull J (1987) Balanced-budget redistribution as the outcome of political competition. Public Choice 52: 273-297.

Matakos K and Xefteris D (2016) Citizens or Clients? Evidence on Opportunistic Voting from a Natural Experiment in Greece. Political Science Research and Methods 4: 493-531.

Matsubayashi T (2013) Do politicians shape public opinion? British Journal of Political Science 43: $451-478$.

Mechtel M and Potrafke N (2013) Electoral cycles in active labor market policies. Public Choice 156: $181-194$.

Murrell P (1985) The size of public employment: an empirical study. Journal of Comparative Economics 9: 424-437.

OECD. (2014) Education at a Glance 2014: OECD Indicators. Paris: OECD Publishing. OECD. (2015a) Health at a Glance 2015: OECD Indicators. Paris: OECD Publishing.

OECD. (2015b) Government at a Glance 2015. Paris: OECD Publishing.

Potrafke N (2017) Partisan politics: the empirical evidence from OECD panel studies. Journal of Comparative Economics 45(4): 712-750.

Potrafke N (2018) Does public sector outsourcing decrease public employment? Empirical evidence from OECD countries. Ifo Working Papers 2672018.

Robinson JA and Verdier T (2013) The political economy of clientelism. Scandinavian Journal of Economics 115: 261-291.

Rogoff K (1990) Equilibrium political budget cycles. American Economic Review 80: 21-36.

Rogowski R (2013) Shooting (or ignoring) the messenger. Political Studies Review 11: 216-221.

Shi M and Svensson J (2006) Political budget cycles: do they differ across countries and why? Journal of Public Economics 90: 1367-1389. 
Stolfi F and Hallerberg M (2015) Clientelistic budget cycles: evidence from health policy in the Italian regions. Journal of European Public Policy 23: 833-850.

Strom K (1990) A behavioral theory of competitive political parties. American Journal of Political Science 34: 565-598.

Tavares J (2004) Does right or left matter? Cabinets, credibility and fiscal adjustments. Journal of Public Economics 88: 2447-2468.

Tepe M (2012) The public/private sector cleavage revisited: the impact of government employment on political attitudes and behaviour in 11 West European countries. Public Administration 90: $230-261$.

Tepe M and Vanhuyesse P (2009) Educational business cycles: the political economy of teacher hiring across German states, 1992-2004. Public Choice 139: 61-82.

Tepe M and Vanhuyesse P (2013) Cops for hire? The political economy of police employment in the German states. Journal of Public Policy 33: 165-199.

Visser J (2006) Union membership statistics in 24 countries. MLR 129: 38-49.

Volkens A, Lehmann P, Matthieß T, Merz N, Regel S and Werner A (2015) The Manifesto Data Collection. Manifesto Project (MRG/CMP/MARPOR). Version 2015a. Berlin:

Wissenschaftszentrum Berlin für Sozialforschung (WZB). Available from https://manifestoproject.wzb.eu/, accessed 2 November 2015.

Wooldridge JM (2006) Introductory Econometrics: A Modern Approach. Mason: Thomson/SouthWestern. 


\section{Appendix A: Correlation matrix for independent variables}

\begin{tabular}{|c|c|c|c|c|c|c|}
\hline & $\begin{array}{c}\text { Left-wing chief } \\
\text { executive (dummy) }\end{array}$ & Election & $\begin{array}{c}\text { GDP per capita } \\
(1000)\end{array}$ & $\begin{array}{l}\text { GDP growth } \\
\text { rate }\end{array}$ & Unemployment & Expenditure \\
\hline Left-wing chief executive (dummy) & 1.00 & & & & & \\
\hline Election & 0.01 & 1.00 & & & & \\
\hline GDP per capita $(1,000)$ & -0.21 & -0.02 & 1.00 & & & \\
\hline GDP growth rate & 0.05 & 0.02 & 0.03 & 1.00 & & \\
\hline Unemployment & -0.03 & -0.02 & -0.52 & -0.03 & 1.00 & \\
\hline Expenditure & 0.05 & -0.00 & -0.27 & -0.27 & 0.35 & 1.00 \\
\hline
\end{tabular}




\section{Appendix B: Full partisan regression models}

\begin{tabular}{|c|c|c|c|c|c|c|c|c|c|c|}
\hline & 1 & 2 & 3 & 4 & 5 & 6 & 7 & 8 & 9 & 10 \\
\hline $\begin{array}{l}\text { Left-wing chief } \\
\text { executive (dummy) }\end{array}$ & $\begin{array}{c}0.043 \\
(0.214)\end{array}$ & $\begin{array}{l}-0.102 \\
(0.210)\end{array}$ & $\begin{array}{l}-0.035 \\
(0.228)\end{array}$ & $\begin{array}{l}-0.065 \\
(0.204)\end{array}$ & $\begin{array}{l}-0.025 \\
(0.232)\end{array}$ & $\begin{array}{l}-0.066 \\
(0.203)\end{array}$ & $\begin{array}{l}-0.074 \\
(0.208)\end{array}$ & $\begin{array}{l}-0.082 \\
(0.175)\end{array}$ & $\begin{array}{l}-0.076 \\
(0.209)\end{array}$ & $\begin{array}{l}-0.083 \\
(0.177)\end{array}$ \\
\hline Election & - & - & - & - & - & - & - & - & $\begin{array}{c}0.076 \\
(0.066)\end{array}$ & $\begin{array}{c}0.041 \\
(0.056)\end{array}$ \\
\hline GDP per capita $(1,000)$ & - & - & $\begin{array}{l}-0.056 \\
(0.065)\end{array}$ & $\begin{array}{c}0.201 \\
(0.116)^{*}\end{array}$ & $\begin{array}{l}-0.045 \\
(0.081)\end{array}$ & $\begin{array}{c}0.200 \\
(0.115)^{*}\end{array}$ & $\begin{array}{l}-0.025 \\
(0.079)\end{array}$ & $\begin{array}{c}0.236 \\
(0.121)^{*}\end{array}$ & $\begin{array}{l}-0.025 \\
(0.080)\end{array}$ & $\begin{array}{c}0.236 \\
(0.122)^{*}\end{array}$ \\
\hline GDP growth rate & - & - & $\begin{array}{l}-0.016 \\
(0.029)\end{array}$ & $\begin{array}{l}-0.079 \\
(0.058)\end{array}$ & $\begin{array}{l}-0.009 \\
(0.022)\end{array}$ & $\begin{array}{l}-0.079 \\
(0.062)\end{array}$ & $\begin{array}{c}0.047 \\
(0.031)\end{array}$ & $\begin{array}{l}-0.003 \\
(0.070)\end{array}$ & $\begin{array}{c}0.046 \\
(0.031)\end{array}$ & $\begin{array}{l}-0.003 \\
(0.069)\end{array}$ \\
\hline Unemployment & - & - & - & - & $\begin{array}{c}0.035 \\
(0.071)\end{array}$ & $\begin{array}{l}-0.004 \\
(0.061)\end{array}$ & $\begin{array}{l}-0.040 \\
(0.085)\end{array}$ & $\begin{array}{l}-0.064 \\
(0.058)\end{array}$ & $\begin{array}{l}-0.040 \\
(0.086)\end{array}$ & $\begin{array}{l}-0.063 \\
(0.058)\end{array}$ \\
\hline Expenditure & - & - & - & - & - & - & $\begin{array}{c}0.101 \\
(0.048)^{* *}\end{array}$ & $\begin{array}{c}0.117 \\
(0.047)^{*}\end{array}$ & $\begin{array}{c}0.101 \\
(0.048)^{* *}\end{array}$ & $\begin{array}{c}0.117 \\
(0.047)^{* *}\end{array}$ \\
\hline Country-fixed effects & Yes & Yes & Yes & Yes & Yes & Yes & Yes & Yes & Yes & Yes \\
\hline Year-fixed effects & No & Yes & No & Yes & No & Yes & No & Yes & No & Yes \\
\hline Within R-squared & 0.001 & 0.222 & 0.034 & 0.354 & 0.039 & 0.354 & 0.106 & 0.430 & 0.108 & 0.431 \\
\hline Number of countries & 22 & 22 & 22 & 22 & 22 & 22 & 22 & 22 & 22 & 22 \\
\hline Observations & 273 & 273 & 273 & 273 & 273 & 273 & 270 & 270 & 270 & 270 \\
\hline
\end{tabular}

Dependent variable is public employment as a share of total labour force. OLS-estimates with standard errors clustered by country in parentheses.

$* \mathrm{p}<0.10$.

$* * \mathrm{p}<0.05$.

$* * * \mathrm{p}<0.01$ 


\section{Appendix C: Full partisan regression models using the Manifesto rile indicator}

\begin{tabular}{|c|c|c|c|c|c|c|c|c|c|c|c|c|}
\hline & 1 & 2 & 3 & 4 & 5 & 6 & 7 & 8 & 9 & 10 & 11 & 12 \\
\hline $\begin{array}{l}\text { Left-right (rile) } \\
\text { placement of the chief } \\
\text { executive's party }\end{array}$ & $\begin{array}{c}0.011 \\
(0.007)\end{array}$ & $\begin{array}{c}0.007 \\
(0.006)\end{array}$ & $\begin{array}{c}0.009 \\
(0.007)\end{array}$ & $\begin{array}{c}0.009 \\
(0.006)\end{array}$ & $\begin{array}{c}0.009 \\
(0.007)\end{array}$ & $\begin{array}{c}0.009 \\
(0.006)\end{array}$ & $\begin{array}{c}0.009 \\
(0.006)\end{array}$ & $\begin{array}{c}0.007 \\
(0.006)\end{array}$ & $\begin{array}{c}0.009 \\
(0.006)\end{array}$ & $\begin{array}{c}0.007 \\
(0.006)\end{array}$ & $\begin{array}{c}0.008 \\
(0.006)\end{array}$ & $\begin{array}{c}0.007 \\
(0.006)\end{array}$ \\
\hline Election & - & - & - & - & - & - & - & - & $\begin{array}{c}0.055 \\
(0.064)\end{array}$ & $\begin{array}{c}0.054 \\
(0.055)\end{array}$ & $\begin{array}{c}0.053 \\
(0.053)\end{array}$ & - \\
\hline $\begin{array}{l}\text { GDP per capita } \\
(1,000)\end{array}$ & - & - & $\begin{array}{l}-0.045 \\
(0.063)\end{array}$ & $\begin{array}{c}0.209 \\
(0.114)^{*}\end{array}$ & $\begin{array}{l}-0.036 \\
(0.078)\end{array}$ & $\begin{array}{c}0.208 \\
(0.113)^{*}\end{array}$ & $\begin{array}{l}-0.014 \\
(0.076)\end{array}$ & $\begin{array}{c}0.243 \\
(0.119)^{*}\end{array}$ & $\begin{array}{l}-0.014 \\
(0.076)\end{array}$ & $\begin{array}{c}0.244 \\
(0.120)^{*}\end{array}$ & $\begin{array}{c}0.243 \\
(0.120)^{*}\end{array}$ & $\begin{array}{c}0.243 \\
(0.119)^{*}\end{array}$ \\
\hline GDP growth rate & - & - & $\begin{array}{l}-0.013 \\
(0.029)\end{array}$ & $\begin{array}{l}-0.082 \\
(0.057)\end{array}$ & $\begin{array}{l}-0.007 \\
(0.022)\end{array}$ & $\begin{array}{l}-0.083 \\
(0.062)\end{array}$ & $\begin{array}{c}0.047 \\
(0.031)\end{array}$ & $\begin{array}{l}-0.005 \\
(0.070)\end{array}$ & $\begin{array}{c}0.047 \\
(0.031)\end{array}$ & $\begin{array}{l}-0.006 \\
(0.070)\end{array}$ & $\begin{array}{l}-0.006 \\
(0.070)\end{array}$ & $\begin{array}{l}-0.005 \\
(0.071)\end{array}$ \\
\hline Unemployment & - & - & - & - & $\begin{array}{c}0.032 \\
(0.068)\end{array}$ & $\begin{array}{l}-0.007 \\
(0.061)\end{array}$ & $\begin{array}{l}-0.040 \\
(0.083)\end{array}$ & $\begin{array}{l}-0.064 \\
(0.058)\end{array}$ & $\begin{array}{l}-0.040 \\
(0.083)\end{array}$ & $\begin{array}{l}-0.064 \\
(0.058)\end{array}$ & $\begin{array}{l}-0.064 \\
(0.058)\end{array}$ & $\begin{array}{l}-0.064 \\
(0.058)\end{array}$ \\
\hline Expenditure & - & - & - & - & - & - & $\begin{array}{c}0.099 \\
(0.047)^{* *}\end{array}$ & $\begin{array}{c}0.117 \\
(0.048)^{* *}\end{array}$ & $\begin{array}{c}0.099 \\
(0.047)^{* *}\end{array}$ & $\begin{array}{c}0.117 \\
(0.048)^{* *}\end{array}$ & $\begin{array}{c}0.118 \\
(0.048)^{* *}\end{array}$ & $\begin{array}{c}0.118 \\
(0.049)^{* *}\end{array}$ \\
\hline $\begin{array}{l}\text { Left-right placement } \times \\
\text { election }\end{array}$ & - & - & - & - & - & - & - & - & - & - & $\begin{array}{l}-0.003 \\
(0.004)\end{array}$ & - \\
\hline Exogenous election & - & - & - & - & - & - & - & - & - & - & - & $\begin{array}{l}-0.023 \\
(0.046)\end{array}$ \\
\hline $\begin{array}{l}\text { Left-right placement } \times \\
\text { exogenous election }\end{array}$ & - & - & - & - & - & - & - & - & - & - & - & $\begin{array}{l}-0.002 \\
(0.005) \\
\end{array}$ \\
\hline Country-fixed effects & Yes & Yes & Yes & Yes & Yes & Yes & Yes & Yes & Yes & Yes & Yes & Yes \\
\hline Year-fixed effects & No & Yes & No & Yes & No & Yes & No & Yes & No & Yes & Yes & Yes \\
\hline Within R-squared & 0.024 & 0.218 & 0.046 & 0.359 & 0.050 & 0.360 & 0.117 & 0.436 & 0.118 & 0.437 & 0.438 & 0.437 \\
\hline Number of countries & 21 & 21 & 21 & 21 & 21 & 21 & 21 & 21 & 21 & 21 & 21 & 21 \\
\hline Observations & 267 & 267 & 267 & 267 & 267 & 267 & 264 & 264 & 264 & 264 & 264 & 264 \\
\hline
\end{tabular}

Dependent variable is public employment as a share of total labour force OLS-estimates with standard errors clustered by country in parentheses.

$* \mathrm{p}<0.10$.

$* * \mathrm{p}<0.05$

$* * * \mathrm{p}<0.01$ 


\section{Appendix D: Full partisan regression models using percentage of left-wing cabinet members}

\begin{tabular}{|c|c|c|c|c|c|c|c|c|c|c|c|c|}
\hline & 1 & 2 & 3 & 4 & 5 & 6 & 7 & 8 & 9 & 10 & 11 & 12 \\
\hline $\begin{array}{l}\text { Percentage of left- } \\
\text { wing cabinet } \\
\text { members }\end{array}$ & $\begin{array}{l}-0.001 \\
(0.004)\end{array}$ & $\begin{array}{l}-0.001 \\
(0.003)\end{array}$ & $\begin{array}{l}-0.001 \\
(0.003)\end{array}$ & $\begin{array}{l}-0.000 \\
(0.003)\end{array}$ & $\begin{array}{l}-0.001 \\
(0.003)\end{array}$ & $\begin{array}{l}-0.000 \\
(0.003)\end{array}$ & $\begin{array}{l}-0.001 \\
(0.003)\end{array}$ & $\begin{array}{l}-0.000 \\
(0.003)\end{array}$ & $\begin{array}{l}-0.001 \\
(0.003)\end{array}$ & $\begin{array}{l}-0.000 \\
(0.003)\end{array}$ & $\begin{array}{c}0.000 \\
(0.002)\end{array}$ & $\begin{array}{l}-0.001 \\
(0.002)\end{array}$ \\
\hline Election & - & - & - & - & - & - & - & - & $\begin{array}{c}0.074 \\
(0.062)\end{array}$ & $\begin{array}{c}0.039 \\
(0.053)\end{array}$ & $\begin{array}{c}0.101 \\
(0.081)\end{array}$ & - \\
\hline $\begin{array}{l}\text { GDP per capita } \\
(1,000)\end{array}$ & - & - & $\begin{array}{l}-0.056 \\
(0.063)\end{array}$ & $\begin{array}{c}0.201 \\
(0.116)^{*}\end{array}$ & $\begin{array}{l}-0.046 \\
(0.079)\end{array}$ & $\begin{array}{c}0.201 \\
(0.114)^{*}\end{array}$ & $\begin{array}{l}-0.024 \\
(0.077)\end{array}$ & $\begin{array}{c}0.236 \\
(0.121)^{*}\end{array}$ & $\begin{array}{l}-0.024 \\
(0.077)\end{array}$ & $\begin{array}{c}0.236 \\
(0.121)^{*}\end{array}$ & $\begin{array}{c}0.235 \\
(0.122)^{*}\end{array}$ & $\begin{array}{c}0.237 \\
(0.120)\end{array}$ \\
\hline GDP growth rate & - & - & $\begin{array}{l}-0.015 \\
(0.029)\end{array}$ & $\begin{array}{l}-0.080 \\
(0.058)\end{array}$ & $\begin{array}{l}-0.008 \\
(0.022)\end{array}$ & $\begin{array}{l}-0.080 \\
(0.062)\end{array}$ & $\begin{array}{c}0.047 \\
(0.031)\end{array}$ & $\begin{array}{l}-0.004 \\
(0.070)\end{array}$ & $\begin{array}{c}0.047 \\
(0.031)\end{array}$ & $\begin{array}{l}-0.004 \\
(0.070)\end{array}$ & $\begin{array}{l}-0.006 \\
(0.070)\end{array}$ & $\begin{array}{l}-0.002 \\
(0.071)\end{array}$ \\
\hline Unemployment & - & - & - & - & $\begin{array}{c}0.034 \\
(0.071)\end{array}$ & $\begin{array}{c}-0.002 \\
(0.061)\end{array}$ & $\begin{array}{l}-0.040 \\
(0.085)\end{array}$ & $\begin{array}{l}-0.062 \\
(0.059)\end{array}$ & $\begin{array}{l}-0.039 \\
(0.085)\end{array}$ & $\begin{array}{l}-0.061 \\
(0.060)\end{array}$ & $\begin{array}{l}-0.063 \\
(0.060)\end{array}$ & $\begin{array}{l}-0.060 \\
(0.060)\end{array}$ \\
\hline Expenditure & - & - & - & - & - & - & $\begin{array}{c}0.100 \\
(0.048)^{* *}\end{array}$ & $\begin{array}{c}0.116 \\
(0.048)^{* *}\end{array}$ & $\begin{array}{c}0.100 \\
(0.048)^{* *}\end{array}$ & $\begin{array}{c}0.116 \\
(0.048)^{* *}\end{array}$ & $\begin{array}{c}0.117 \\
(0.048)^{* *}\end{array}$ & $\begin{array}{c}0.115 \\
(0.047)^{* *}\end{array}$ \\
\hline $\begin{array}{l}\text { Left-wing cabinet } \\
\text { members } \times \\
\text { election }\end{array}$ & - & - & - & - & - & - & - & - & - & - & $\begin{array}{l}-0.002 \\
(0.002)\end{array}$ & - \\
\hline Exogenous election & - & - & - & - & - & - & - & - & - & - & - & $\begin{array}{l}-0.077 \\
(0.078)\end{array}$ \\
\hline $\begin{array}{l}\text { Left-wing cabinet } \\
\text { members } \times \\
\text { exogenous election }\end{array}$ & - & - & - & - & - & - & - & - & - & - & - & $\begin{array}{c}0.002 \\
(0.002)\end{array}$ \\
\hline $\begin{array}{l}\text { Country-fixed } \\
\text { effects }\end{array}$ & Yes & Yes & Yes & Yes & Yes & Yes & Yes & Yes & Yes & Yes & Yes & Yes \\
\hline Year-fixed effects & No & Yes & No & Yes & No & Yes & No & Yes & No & Yes & Yes & Yes \\
\hline Within R-squared & 0.001 & 0.222 & 0.036 & 0.353 & 0.041 & 0.353 & 0.108 & 0.429 & 0.109 & 0.429 & 0.430 & 0.430 \\
\hline $\begin{array}{l}\text { Number of } \\
\text { countries }\end{array}$ & 22 & 22 & 22 & 22 & 22 & 22 & 22 & 22 & 22 & 22 & 22 & 22 \\
\hline Observations & 273 & 273 & 273 & 273 & 273 & 273 & 273 & 270 & 270 & 270 & 270 & 270 \\
\hline
\end{tabular}

Dependent variable is public employment as a share of total labour force. OLS-estimates with standard errors clustered by country in parentheses.

$* \mathrm{p}<0.10$.

$* * \mathrm{p}<0.05$.

$* * * \mathrm{p}<0.01$. 